\title{
Comparative Study of TANUVAS Aseel and Desi Chicken Rearing Under Backyard in Rural Areas of Tiruppur District in Tamil Nadu, India
}

\section{P. Chitra}

Krishi Vigyan Kendra, Tiruppur, Tamil Nadu Agricultural University, Tamil Nadu, India

Corresponding author: drpchithupsc@gmail.com (ORCID ID: 0000-0001-6148-721X)

Paper No. 934

Received: 29-07-2021

Revised: $30-08-2021$

Accepted: 10-09-2021

\begin{abstract}
The present study was conducted by ICAR Krishi Vigyan Kendra, Tiruppur to assess the productive and reproductive performance of TANUVAS Aseel and local desi chicken under backyard rearing system in Tiruppur district of Tamil Nadu, India. A total of five hundred day old TANUVAS Aseel chicks were procured and distributed to 25 farm women each with 20 day old chicks who possessed 20 numbers of local desi chicken rearing under backyard system. A field level study was undertaken to evaluate efficiency of productive and reproductive performance of TANUVAS Aseel and local desi chicken under backyard system with respect to average body weight at $8^{\text {th }}, 12^{\text {th }}, 16^{\text {th }}$ week of age, body weight at first egg laying, age at the point of lay, egg weight and egg production upto 20 and 72 weeks of age, fertility and hatchability percentage. TANUVAS Aseel chicken body weight at $8^{\text {th }}, 12^{\text {th }}$ and $16^{\text {th }}$ week of age, body weight at first egg laying, age at the point of lay and egg production upto 40 and 72 weeks, egg weight, fertility \% and hatchability \% were $0.57 \pm 0.92 \mathrm{~kg}, 1.15 \pm 0.69 \mathrm{~kg}, 1.41 \pm 0.26 \mathrm{~kg}, 1.65 \pm 0.98 \mathrm{~kg}, 159.0 \pm 0.24$ days, $42.5 \pm 0.32,134.6 \pm 0.18,52.5 \pm 0.73 \mathrm{~g}, 91.2 \pm 0.36,85.6 \pm 0.25$ respectively. TANUVAS Aseel chicken birds are well adopted for rural areas under backyard system of rearing. TANUVAS Aseel chicken exhibit better productive and reproductive performance compared to local country chicken under backyard rearing. It is well accepted strain by rural areas of Tamil Nadu and also improved the socio economic status of rural people and rural women empowerment. Besides income generation, TANUVAS Aseel reared under backyard helps to alleviate the malnutrition of the rural people through production of valuable animal protein. The present study was concluded that TANUVAS Aseel birds can serve as an alternate improved strain to boost up the economic status of rural people.
\end{abstract}

\section{HIGHLIGHTS}

0 The average body weight at $8^{\text {th }}, 12^{\text {th }}, 16^{\text {th }}$ week of age, body weight at first egg laying, age at the point of lay, egg weight and egg production upto 20 and 72 weeks of age, fertility and hatchability percentage of TANUVAS Aseel was better than the production performance of desi chickens.

- TANUVAS Aseel chicken is performing well under backyard system rural areas of Tiruppur district, farmers can rear this bird to improve their livelihood and for nutritional security.

Keywords: TANUVAS Aseel, Backyard rearing, Body weight, Egg weight, Egg production, Fertility \%, Hatchability \%

Backyard poultry farming is traditional system poultry rearing in rural areas of India. Backyard poultry is a handy and promising enterprise with low cost investment but high economic return along with production of rural empowerment. Dhaka et al. (2017) reported that rural people family income and nutritional requirement mainly depend on backyard poultry farming. Country chicken egg and

How to cite this article: Chitra, P. 2021. Comparative Study of TANUVAS Aseel and Desi Chicken Rearing Under Backyard in Rural Areas of Tiruppur District in Tamil Nadu, India. IJAEB, 14(03): 485-488. Source of Support: None; Conflict of Interest: None (क) ब 
meat is one among the best and cheapest source of animal protein in rural people of India. Feed cost is negligible due to better utilisation of agricultural by products and left over feed and grain.

In India, 25 per cent (Vetrivel and Chandrakumarmangalam 2013) of total poultry population is contributed by desi chicken, which also makes a limited contribution to the GDP. The awareness created among the younger generation motivates the farmers to rear desi chicken in rural areas.

Backyard poultry is a handy and promising enterprise to improve the socio economic improvement among the weaker sections of society; especially landless labour, small and marginal farm women's households in rural areas with low-cost initial investment and high economic return along with guarantee for improving protein deficiency among the poor. Though India has shown a tremendous growth in poultry production over decades but poultry farming in individual household level is still lagging behind and always found neglected as they were rearing desi type chickens having low egg and meat production potential. The potentiality of desi birds in terms of egg production is only 60 to 90 eggs/ bird/ year and meat production is also very low (Patra and Singh 2016). However, the backyard poultry production system can be enhanced by adopting improved breeds of chicken that can promise better production of meat and egg.

Improving the performance of indigenous breeds in rural area TANUVAS Aseel strain developed by Poultry Research Station, Tamil Nadu Veterinary and Animal Sciences University, Chennai and released during the foundation day of the University held on 10.11.2017. This dual-purpose bird is well received by farming community because of its better growth gate and egg production capability. However, very scanty information is available regarding production and reproduction performance of TANUVAS Aseel chicken in rural areas under backyard rearing. Hence, the present study was carried out to evaluate the production and reproduction performance of TANUVAS Aseel and local desi chicken under backyard rearing in Tiruppur district of Tamil Nadu, India.

\section{TANUVAS Aseel Chicken}

Tamil Nadu Veterinary and Animal Science University collected strains of Aseel from Central
Poultry Development Organisation (CPDO), Bhubaneswar (Base population), Directorate (DPR), Hyderabad and from a private entrepreneur and champion breeders. All the birds were brought into the genetic pool and random breeding was carried out. Higher body weight of male birds were selected by Individual selection and higher egg production of female birds were selected by family selection. A multi coloured plumage, dual purpose, good disease resistance, native variety of TANUVAS Aseel breed was evolved with continuous selection and breeding for six generations. TNAUVAS Aseel highly suited for backyard rearing under different agro - climatic conditions of Tamil Nadu.

\section{Characteristics of TANUVAS Aseel}

TANUVAS Aseel breed having reddish brown plumage, pea comb and close feathering. The face is long and slender. The eyes are compact, well set and present bold looks. Wattles and ear lobes are bright red and beak is hard. The neck is long, uniformly thick but not fleshy. The legs are strong, straight and the tail is small and drooping. Birds laying dark brown shelled eggs with thick shell.

\section{MATERIALS AND METHODS}

The present study was carried out by ICAR Krishi Vigyan Kendra, Tiruppur, Tamil Nadu to assess the performance of TANUVAS Aseel and desi chicken under backyard system of rearing. For this study, farm women were selected randomly in different five villages of Tiruppur district. The selected farmwomen were trained in all scientific chicken training techniques like brooding, feeding, deworming and vaccination.

A total of 500 day-old chicks of TANUVAS Aseel chicks were procured from Tamil Nadu Veterinary and Animal Sciences University farm and distributed to the 25 numbers of farm women each with 20 day old chicks. On arrival, all chicks were provided electrolytes and vitamin supplements in clean drinking water and then distributed to the farm women.

The brooding was carried out for a period of 28 days (4 weeks) using electric bulbs as sources of heat and illumination. Chicks were brooded at a temperature of $95^{\circ} \mathrm{F}$ with adequate water and feeding spaces provided. Light was provided for 23 hours during first week of brooding to avoid pilling 
and death. Temperature can be reduced by $5^{\circ} \mathrm{F}$ every week until 4 weeks of age. Standard management and healthcare practices were followed throughout the experimental period and chick starter ration was provided to the chicks up to 4 weeks of age. After proper brooding, the chicks were moved into freely and reared in backyard system like local desi chicken. Birds were periodically vaccinated against Ranikhet disease.

The demonstrated fields were regularly monitored and periodically observed. The body weight of all the birds were recorded at day old age and also monthly intervals up to maturity at an average body weight $8^{\text {th }}, 12^{\text {th }}$ and $16^{\text {th }}$ week of age, average body weight at first egg laying, average age at the point of lay, average egg weight, average egg production per annum. The mortality of birds were observed, fertility and hatchability percentage were also recorded for a period of one and half year. Egg production was recorded daily and the eggs were weighed every day in the afternoon immediately after collection. For study of fertility and hatchability percentage, every week, each 200 numbers of eggs from TANUVAS Aseel chicken were collected and set in a small scale incubator.

\section{RESULTS AND DISCUSSION}

The production performance of TANUVAS Aseel and desi chicken are presented in Table 1.

Table 1

\begin{tabular}{|c|c|c|c|}
\hline $\begin{array}{l}\text { Sl. } \\
\text { No }\end{array}$ & Parameter & $\begin{array}{l}\text { TANUVAS } \\
\text { Aseel }\end{array}$ & $\begin{array}{l}\text { Desi } \\
\text { Chicken }\end{array}$ \\
\hline \multirow[t]{6}{*}{1} & Body weight & & \\
\hline & $\begin{array}{l}\text { Body weight Day old age } \\
\text { (g) }\end{array}$ & $37.25 \pm 0.62$ & $36.86 \pm 0.27$ \\
\hline & $\begin{array}{l}\text { Body weight } 8^{\text {th }} \text { week of } \\
\text { age }(\mathrm{Kg})\end{array}$ & $0.57 \pm 0.92$ & $0.49 \pm 0.84$ \\
\hline & $\begin{array}{l}\text { Body weight } 12^{\text {th }} \text { week of } \\
\text { age }(\mathrm{Kg})\end{array}$ & $1.15 \pm 0.69$ & $0.98 \pm 0.71$ \\
\hline & $\begin{array}{l}\text { Body weight at } 16^{\text {th }} \text { weeks } \\
\text { of age }(\mathrm{Kg})\end{array}$ & $1.41 \pm 0.26$ & $1.23 \pm 0.26$ \\
\hline & $\begin{array}{l}\text { Body weight at first egg } \\
\text { laying }\end{array}$ & $1.65 \pm 0.98$ & $1.45 \pm 0.72$ \\
\hline 2 & Age at first egg lay (Days) & $159 \pm 0.24$ & $172 \pm 0.24$ \\
\hline \multirow[t]{3}{*}{3} & Egg production (Nos.) & & \\
\hline & Upto 40 weeks of age & $42.5 \pm 0.32$ & $28.5 \pm 0.32$ \\
\hline & Upto 72 weeks of age & $134.6 \pm 0.18$ & $92.5 \pm 0.32$ \\
\hline 4 & Average Egg weight (g) & $52.5 \pm 0.73$ & $44.6 \pm 0.86$ \\
\hline
\end{tabular}

5 Livability \%

\begin{tabular}{lll} 
Upto 12 weeks of age & $97.5 \pm 0.62$ & $91.5 \pm 0.78$ \\
Upto 72 weeks of age & $94.2 \pm 0.45$ & $87.4 \pm 0.69$ \\
Fertility \% & $91.2 \pm 0.36$ & $84.5 \pm 0.39$ \\
Hatchability \% & $85.6 \pm 0.25$ & $80.4 \pm 0.67$ \\
\hline
\end{tabular}

Body weight is the direct reflection of growth and it influences the production and reproduction performance of birds. The present study revealed that the average body weight of Aseel chicken at $8^{\text {th }}, 12^{\text {th }}, 16^{\text {th }}$ week of age was recorded as $0.57 \pm 0.92$ $\mathrm{kg}, 1.15 \pm 0.69 \mathrm{~kg}$ and $1.41 \pm 0.26 \mathrm{~kg}$ respectively. In case of desi chicken average body weight at $8^{\text {th }}, 12^{\text {th }}$, $16^{\text {th }}$ week of age was recorded as $0.49 \pm 0.84 \mathrm{~kg}, 0.98$ $\pm 0.71 \mathrm{~kg}$ and $1.23 \pm 0.26$ respectively. The average age at first egg production in desi chicken was 172 \pm 0.24 days which was more when compared with TANUVAS Aseel chicken $159 \pm 0.24$ days. However, age at first egg production was 144 days reported by Ezhil Valavan et al. (2016) and 154 days by Mohan et al. (2008). In contrary to the above findings, Singh et al. (2000) reported that the age at sexual maturity of the Aseel was 29 week under field conditions.

Age at first egg production is influenced by many environmental factors, such as temperature, nutrition and day length.

Egg production determine the success of poultry enterprise. The comparative estimate of egg production revealed that egg production for TANUVAS Aseel chicken $(134.6 \pm 0.18)$ is comparatively higher than desi chicken egg production $(92.5 \pm 0.32$ ). This value for this parameter is higher in comparison with previous report of Aseel chicken with range of 18 to 64 eggs (Haunshi et al. 2011; Vij et al. 2006; Rajkumar et al. 2017). Ezhilvalavan et al. (2016) reported the mean egg production of 159 eggs per bird from 20-72 weeks of age. The prominent broodiness character might be the primary reason for lower production in native chickens in general and Aseel in particular. The average egg weight of TANUVAS Aseel chicken and desi chicken $52.5 \mathrm{gm}$ and 44.6 gm respectively. Egg production and egg weight of TANUVAS Aseel chicken were higher than for the desi chickens kept under backyard system. TANUVAS Aseel chicken livability percentage upto 12 and 72 weeks was recorded in our study was 97.5 and 94.2 respectively. However, Ezhil Valavan et al. (2016) observed that Livability of Aseel was 94.29 percentage. The 
average fertility and hatchability percentage of TANUVAS Aseel chicken recorded as $91.2 \pm 0.36$ and 85.6 \pm 0.25 respectively. However, Rajkumar et al. (2017) reported low fertility rate as $67.18 \%$, hatchability as $44.71 \%$ on total eggs set and $80.87 \%$ on fertile eggs set in Aseel chicken. The fertility was influenced many factors like breed, nutrition, age, and management practices of birds. The variations in fertility and hatchability might be due to the differences in age of the birds and environmental conditions.

\section{CONCLUSION}

The present study revealed that the average body weight at $8^{\text {th }}, 12^{\text {th }}, 16^{\text {th }}$ week of age, body weight at first egg laying, age at the point of lay, egg weight and egg production upto 20 and 72 weeks of age, fertility and hatchability percentage of TANUVAS Aseel was better than the production performance of desi chickens. TANUVAS Aseel chicken is performing well under backyard system rural areas of Tiruppur district, farmers can rear this bird to improve their livelihood and for nutritional security.

\section{REFERENCES}

Dhaka, B.L., Meema, G.S., Bhairwa, R.K. and Meena, N.L. 2017. Supplementing rural livelihood through backyard poultry farming. Int. J of Curr. Microbiol. App. Sci., 6(4): 1412-1415.

Haunshi, S., Niranjan, M., Shanmugam, M., Padhi, M.K., Reddy, M.R. and Sunitha, R. 2011. Characterization of two Indian native chicken breeds for production, egg and semen quality, and welfare traits. Poult. Sci., 90: 314-320.
Ezhilvalavan, S., Omprakash, A.V., Bharathidhasan, A. and Rameshsaravanakumar, V. 2016. Production performance of Aseel under Indian tropical condition. Int. J App. Pure Sci. and Agri., 2(11): 107-110.

Maurya, S.K. and Yadav, B.M. 2018. Prolactin gene and laying performance in Aseel birds. Int. J. Avian and Wildlife Bio., 3: 75-76.

Mohan, J., Sastry, K.V.H., Moudgal, R.P and Tyagi, J.S. 2008. Production and other characteristics of Aseel Peela desi hens under normal rearing system. Int. J. Poult. Sci., 43: 217-219.

Patra, J. and Singh, D.V. 2016. Backyard poultry farming, a suitable Intervention for Tribal people for their livelihood support and Nutritional security. Int. J. of Humanities and Soc. Sci. Innov., 5(6): 22-26.

Rajkumar, U., Haunshi, S., Paswan, C., Raju, M.V.L.N., Rama Rao, S.V. and Chatterjee, R.N. 2017. Characterization of indigenous Aseel chicken breed for morphological, growth, production, and meat composition traits from India. J. Poult. Sci., 96: 2120-2126.

Singh, U., Gupta, R.K., Singh, M. and Gurung, B.S. 2000. Reproduction and production performance of Aseel, an indigenous breed of chicken. Int. J. Poult. Sci., 35: 202-204.

Vetrivel, S.C. and Chandrakumarmangalam, S. 2013. The role of poultry industry in Indian economy. Brazilian J Poult. Sci., 15(4): 287-294.

Vij, P.K., Tantia, M.S., Mishra, B., Bharanikumar, S.T. and Vijh, R.K. 2006 Characterization of Aseel, Danki, Kalasthi and Ghagus breeds of chicken. Indian J. Anim. Sci., 76(11): 944-949. 